\title{
CALIOP near-real-time backscatter products compared to EARLINET data
}

\author{
T. Grigas ${ }^{1}$, M. Hervo ${ }^{1, \text { a }}$, G. Gimmestad ${ }^{2}$, H. Forrister ${ }^{2, b}$, P. Schneider ${ }^{3}$, J. Preißler ${ }^{1}$, L. Tarrason ${ }^{3}$ and C. O’Dowd $^{1}$ \\ ${ }^{1}$ School of Physics and Centre for Climate and Air Pollution Studies, Ryan Institute, National University of Ireland Galway, \\ Galway, Ireland \\ ${ }^{2}$ Electro-Optical Systems Laboratory, Georgia Tech Research Institute, Georgia Institute of Technology, 225 North Avenue, \\ Atlanta, Georgia 30332, USA \\ ${ }^{3}$ NILU - Norwegian Institute for Air Research, P.O. Box 100, 2027 Kjeller, Norway \\ a now at: Federal Office of Meteorology and Climatology, MeteoSwiss, Payerne 1530, Switzerland \\ b now at: School of Earth and Atmospheric Sciences, Georgia Institute of Technology, 225, North Avenue, Atlanta, \\ Georgia 30332, USA
}

Correspondence to: T. Grigas (tomas.grigas@nuigalway.ie)

Received: 17 December 2014 - Published in Atmos. Chem. Phys. Discuss.: 4 March 2015

Revised: 15 October 2015 - Accepted: 20 October 2015 - Published: 3 November 2015

\begin{abstract}
The expedited near-real-time Level 1.5 CloudAerosol Lidar with Orthogonal Polarization (CALIOP) version 3 products were evaluated against data from the groundbased European Aerosol Research Lidar Network (EARLINET). The statistical framework and results of the threeyear evaluation of 48 CALIOP overpasses with ground tracks within a $100 \mathrm{~km}$ distance from operating EARLINET stations are presented and include analysis for the following CALIOP classifications of aerosol type: dust, polluted dust, clean marine, clean continental, polluted continental, mixed and/or smoke/biomass burning. For the complete data set comprising both the planetary boundary layer (PBL) and the free troposphere (FT) data, the correlation coefficient $(R)$ was 0.86 . When the analysis was conducted separately for the PBL and FT, the correlation coefficients were $R=0.6$ and $R=0.85$, respectively. From analysis of selected specific cases, it was initially thought that the presence of FT layers, with high attenuated backscatter, led to poor agreement of the PBL backscatter profiles between the CALIOP and EARLINET and prompted a further analysis to filter out such cases; however, removal of these layers did not improve the agreement as $R$ reduced marginally from $R=0.86$ to $R=0.84$ for the combined PBL and FT analysis, increased marginally from $R=0.6$ up to $R=0.65$ for the PBL on its own, and decreased marginally from $R=0.85$ to $R=0.79$ for the FT analysis on its own. This suggests considerable
\end{abstract}

variability, across the data set, in the spatial distribution of the aerosol over spatial scales of $100 \mathrm{~km}$ or less around some EARLINET stations rather than influence from elevated FT layers. For specific aerosol types, the correlation coefficient between CALIOP backscatter profiles and the EARLINET data ranged from $R=0.37$ for polluted continental aerosol in the PBL to $R=0.57$ for dust in the FT.

\section{Introduction}

Aerosols have an impact on the global radiative budget directly via scattering and absorbing incoming and reflected solar radiation, and indirectly via the modification of cloud microphysical properties that lead to changes in cloud radiative properties along with cloud lifetimes (Haywood et al., 2003; Yu et al., 2006). Lidar is a very useful technique for characterising the vertical dispersion of aerosol plumes through examination of the backscatter signal and aerosol properties such as shape, from the depolarisation channel, that can elucidate particle composition, in particular, for Saharan dust or volcanic ash plumes (Groß et al., 2010; Papayannis et al., 2002). Several research programmes in Europe have performed routine long-term observations of the optical properties of different aerosol types (Giannakaki et al., 2009; Mattis et al., 2004, 2008); however, such stud- 
ies were typically limited to single geographical locations. In order to study aerosol transport on a larger spatial scale, lidar networks are deployed (Bösenberg et al., 2003; Pappalardo et al., 2014), in conjunction with space-borne platforms. In 2000, the European Aerosol Research Lidar Network (EARLINET) was established to provide a comprehensive statistically representative data set of the aerosol vertical distribution. At present, 27 European stations contribute to this network by performing the measurements a few times per week according to the schedule (Pappalardo et al., 2014). There are other lidar networks, and one of them is the NASA Micro-Pulse Lidar Network (MPLNET). Twenty-one permanent stations of this network are deployed worldwide from the Arctic to the Antarctic regions, which continuously measure aerosol and cloud vertical structure day and night (Lolli et al., 2014). Furthermore, there is the Global Atmosphere Watch (GAW) Aerosol Lidar Observation Network (GALION), which is based on the cooperation between existing lidar networks: the Latin America Lidar Network (ALINE), the Asian Dust and Aerosol Lidar Observation Network (AD-Net), the Commonwealth of Independent States (CIS) Lidar Network (CIS-LINET), the Canadian Operational Research Aerosol lidar Network (CORALNet), EARLINET, the Network for the Detection of Atmospheric Composition Change (NDACC), the Regional East Atmospheric Lidar Mesonet (REALM/CREST), and MPLNET. Global coverage may be achieved by using satellite-based lidar systems; striving towards such an aim, the National Aeronautics and Space Administration (NASA), in collaboration with the French space agency Centre National d'Etudes Spatiales (CNES), developed a satellite-based lidar system called CALIOP (Cloud-Aerosol Lidar with Orthogonal Polarization), which is on board the CALIPSO satellite platform (Omar et al., 2009; Vaughan et al., 2011). CALIOP performs measurements simultaneously at wavelengths of 532 and $1064 \mathrm{~nm}$. The CALIPSO satellite was launched into orbit in April 2006 and is part of the A-Train constellation of scientific satellites dedicated to observations of the atmosphere (Stephens et al., 2002). It follows a sun-synchronous polar orbit of $705 \mathrm{~km}$ altitude and has a 16-day repeat cycle.

The EARLINET community has performed several comparisons with CALIOP data since its launch in April 2006 (Mattis et al., 2007; Pappalardo et al., 2010) using CALIOP overpasses with ground tracks within $100 \mathrm{~km}$ from EARLINET stations. Several studies inter-comparing CALIOP Level 1 and Level 2 data with the ground-based measurements have been performed in recent years (Mamouri et al., 2009; Molero and Pujadas, 2008; Pappalardo et al., 2009, 2010). Pappalardo et al. (2010) found good agreement between the $532 \mathrm{~nm}$ CALIOP Level 1 attenuated backscatter and EARLINET measurements with a relative mean difference of $4.6 \%$ and a relative standard deviation (SD) of $50 \%$. The attenuated backscatter was used only from those EARLINET stations that provided independent extinction measurements. That allowed (a) calculating the lidar ratio and (b) converting EARLINET backscatter into attenuated backscatter as seen from space at $532 \mathrm{~nm}$ without any assumptions. The correlation coefficient as a function of the CALIOP ground track offset distances was assessed as well. The correlation coefficient $R=0.9$ was found for distances smaller than $100 \mathrm{~km}$, while it decreased rapidly with larger distances. The mean bias between the CALIOP Level 1 and EARLINET Athens station's measurements as assessed by Mamouri et al. (2009) for daytime measurements was $22 \%$, and for night-time measurements it was $8 \%$. In this study, the measurements were averaged approximately for 2 hours and were centred on the CALIOP overpass time. Mona et al. (2009) found a mean difference of $(-2 \pm 12) \%$ between data from the EARLINET station in Potenza and CALIOP Level 1 measurements within the $3-8 \mathrm{~km}$ altitude range, while the mean difference of the measurements within the planetary boundary layer (PBL) was equal to $(-24 \pm 20) \%$. The influence of the presence of cirrus clouds on the measurements was assessed in a study by Mamouri et al. (2009). The mean biases without cirrus clouds were $-26 \pm 22 \%$ for $5 \mathrm{~km}$ horizontal resolution and $-14 \pm 15 \%$ for $20 \mathrm{~km}$; the biases were higher in cirrus cases, with $-104 \pm 129 \%$ for $5 \mathrm{~km}$ horizontal resolution and $-85 \pm 93 \%$ for $20 \mathrm{~km}$.

Assimilation of the CALIOP Level 1 data product into atmospheric models has been carried out successfully in the past using an ensemble Kalman filter (Sekiyama et al., 2010). However, processed CALIOP Level 1 and Level 2 data products are generally only available several days after acquisition at the earliest, thus severely limiting their use for operational data assimilation. An expedited CALIOP Level 1.5 near-real-time (NRT) product, usually provided between 6 and $30 \mathrm{~h}$ after downlink, has been made available by NASA for purposes of operational forecasting since November 2010 (Vaughan et al., 2011). Level 1.5 is derived by cloud-clearing Level 1 attenuated backscatter profiles using the Level 2 vertical feature masks, and then spatially averaging the cloudcleared profiles. Level 1.5 expedited products use a simplified calibration scheme compared to Level 1 and Level 2. Also, it is derived by using the Global Modelling and Assimilation Office (GMAO) molecular model number densities, which can be out of date (sometimes by as much as 2 days). As a result, the scientific quality of the expedited data compared to the standard CALIOP products can be degraded. In Level 1.5 data set, the free troposphere (FT) is limited by $20 \mathrm{~km}$.

The European Centre for Medium-Range Weather Forecasts (ECMWF) is currently evaluating the potential use of an expedited CALIOP Level 1.5 data product (the total attenuated backscatter profile) for assimilation into their global forecasting model IFS-MOZART (Integrated Forecast System coupled to the Model for Ozone And Related chemical Tracers; A. Benedetti, ECMWF, personal communication, 2014) under the Monitoring Atmospheric Composition and Climate (MACC) project. A similar idea of using groundbased lidar measurements in the model assimilation was im- 
plemented in a study by Wang et al. (2013). They found that the root mean square error (RMSE) of $\mathrm{PM}_{10}$ concentrations declined by $54 \%$ when the lidar measurements were used in the assimilation. This indicates the importance of evaluating the CALIOP Level 1.5 data by inter-comparing them with ground-based measurements. The inter-comparison of the $532 \mathrm{~nm}$ wavelength attenuated backscatter profiles between CALIOP and EARLINET reported here was performed for coincident daytime and night-time measurements.

\section{Data and methodology}

The CALIOP instrument directly measures the vertical profile of the total (molecular plus aerosol) attenuated backscatter as seen from above the atmosphere, with a spatial resolution of $30 \mathrm{~m}$ vertically and $333 \mathrm{~m}$ horizontally (Winker et al., 2009). These Level 0 raw data are averaged both horizontally and vertically before they are downlinked to the NASA Langley Research Centre (LaRC), where the scientific data products of the various levels are produced (Level 1, Level 1.5, Level 2 and Level 3). The vertical resolution for this Level 0 varies from $30 \mathrm{~m}(-0.5$ to $8.2 \mathrm{~km})$ up to $300 \mathrm{~m}(30.1$ to $40 \mathrm{~km}$ ), while the horizontal resolution varies from $333 \mathrm{~m}$ ( -0.5 to $8.2 \mathrm{~km}$ ) up to $5 \mathrm{~km}(30.1$ to $40 \mathrm{~km}$ ) (Powell et al., 2010).

CALIOP has an automatic aerosol classification algorithm that uses altitude, location, surface type, volume depolarisation ratio $\delta_{v}$ and integrated attenuated backscatter $\gamma^{\prime}$ at $532 \mathrm{~nm}$ to determine the aerosol type (Burton et al., 2013; Omar et al., 2009). The algorithm detects six main aerosol types: clean marine, polluted dust, dust, polluted continental, clean continental and smoke/burning biomass. Such aerosol type detection is implemented in the Level 2 aerosol subtyping algorithm. The Level 1.5 product does report feature types having the designation "clear air" and "mixed aerosol". The first type is used to describe range bins absent of detected features, while the second type is used if the $20 \mathrm{~km}$ horizontal averages contain more than one of the six CALIOP aerosol types. The Level 2 vertical feature mask provides information on cloud and aerosol layers as well as the type of aerosol in each identified layer.

The Level 1.5 product is derived by spatially averaging 60 individual Level 1 lidar profiles and merging them with the Level 2 vertical feature mask product. It has a spatial resolution of $20 \mathrm{~km}$ horizontally and $60 \mathrm{~m}$ vertically, and it is restricted to the altitude range -0.5 to $20 \mathrm{~km}$ (Powell et al., 2010). The main Level 1.5 parameters used in this work are latitude, longitude, profile UTC time, mean total attenuated backscatter profile at $532 \mathrm{~nm}, \mathrm{SD}$ of the total attenuated backscatter for $532 \mathrm{~nm}$, total attenuated backscatter uncertainty for $532 \mathrm{~nm}$ (CALIPSO Quality Statements, 2011, p. 02), L2 feature type, and lidar ratio, along with the Rayleigh extinction and backscatter cross sections for the molecular atmosphere at $532 \mathrm{~nm}$.
The CALIOP uncertainties of the attenuated backscatter (CALIPSO Quality Statements, 2011) are calculated using the equation

$\sigma_{\mu}=\frac{1}{N} \sqrt{\sum_{i=1}^{N} \sigma_{i}^{2}}$,

where $\sigma_{i}$ is the attenuated backscatter uncertainty at the range bin $\mu$ and $N$ is the number of Level 1 profile range bins.

EARLINET was chosen as the reference network for this inter-comparison. At present, this network is one of the most sophisticated lidar networks in the world. The ground-based lidar measurements used in this study were acquired from the EARLINET portal (www.EARLINET.org) for the period from November 2010 to December 2012 as well as for several days in April and May 2010 during the Eyjafjallajökull volcano eruption. The aerosol backscatter coefficient profiles with uncertainties were provided in each of the EARLINET files. The EARLINET profiles were averaged over the time interval which varied between $30 \mathrm{~min}$ and $2 \mathrm{~h}$. CALIOP-EARLINET inter-comparisons were only considered for coincident overpasses, defined as having a CALIOP ground track within a $100 \mathrm{~km}$ distance from the EARLINET station. The backscatter coefficients provided by EARLINET were converted into total attenuated backscatter values using the method described below.

The CALIOP instrument directly measures profiles of the total attenuated backscatter as seen from space, and NASA provides them in the Level 1.5 data set. These profiles were chosen for the inter-comparison in order to assess CALIOP measurements. The EARLINET stations produce aerosol backscatter coefficients, and so the two different backscatter coefficients cannot be inter-compared directly. For this reason, a method similar to that of Mona et al. (2009) was adopted for converting the EARLINET particulate backscatter coefficients into total attenuated backscatter values as observed from space, thus allowing for a valid inter-comparison of CALIOP and EARLINET measurements. The following equations were used to calculate EARLINET attenuated backscatter. The total attenuated backscatter $\beta_{\text {att }}(z)$ at altitude $z$ is given by

$\beta_{\text {att }}(z)=T^{2}(z) \beta_{\mathrm{tot}}(z)$,

where $T^{2}(z)$ is the two-way transmittance from the lidar in space down to the altitude $z$, and $\beta_{\text {tot }}$ is the total backscatter coefficient, defined as

$\beta_{\mathrm{tot}}(z)=\beta_{\mathrm{par}}(z)+\beta_{\mathrm{mol}}(z)$,

where $\beta_{\mathrm{par}}$ is the particulate (aerosol) backscatter coefficient and $\beta_{\mathrm{mol}}$ is the molecular backscatter coefficient.

In order to calculate the total backscatter coefficient $\beta_{\text {tot }}$, the EARLINET particulate backscatter coefficient is used as $\beta_{\text {par }}$ in Eq. (3) and the molecular backscatter coefficient $\beta_{\text {mol }}$ 
is calculated from the atmospheric temperature and pressure profiles (Sissenwine et al., 1962). The molecular backscatter and extinction cross sections for air appropriate for CALIOP are given in NASA documentation by Powell et al. (2010) as $5.167 \times 10^{-31} \mathrm{~m}^{2}$ and $5.930 \times 10^{-32} \mathrm{~m}^{2} \mathrm{sr}^{-1}$, respectively. Using the methods of Bucholtz et al. (1995), the molecular number density $N_{\mathrm{s}}$ in standard air (defined at reference atmospheric pressure $P_{\mathrm{s}}=1013.25 \mathrm{mbar}$ and temperature $T_{\mathrm{s}}=15^{\circ} \mathrm{C}$ ) is $2.54743 \times 10^{25} \mathrm{~mol} \mathrm{~m}^{-3}$, so (assuming that the atmospheric equation of state is accurately represented by the ideal gas law) the molecular backscattering coefficient at any altitude $h$ is given by

$\beta_{\mathrm{mol}}(h)=\sigma_{\text {back }} N_{\mathrm{s}} \frac{P(h) T_{\mathrm{s}}}{P_{\mathrm{s}} T(h)}$,

where $\sigma_{\text {back }}$ is the backscatter cross section given above, and $P(h)$ and $T(h)$ are the pressure and the temperature of standard atmosphere, respectively. The two-way transmittance for a downward-looking lidar is calculated using the following equation:

$T^{2}(z)=\exp \left[-2 \int_{\text {top }}^{z} \alpha\left(z^{\prime}\right) \mathrm{d} z^{\prime}\right]$,

where top is the highest altitude of the profile (nominally $20 \mathrm{~km})$ and $\alpha(z)$ is the total extinction coefficient, which is the sum of the particle extinction coefficient $\alpha_{\text {par }}$ and the molecular extinction coefficient $\alpha_{\text {mol }}$.

The particle extinction coefficient $\alpha_{\text {par }}$ is calculated according to

$\alpha_{\mathrm{par}}=S_{a} \beta_{\mathrm{par}}$,

where $\beta_{\text {par }}$ is the EARLINET particle backscatter coefficient and $S_{a}$ is the particulate extinction-to-backscatter ratio (commonly known as the lidar ratio). The lidar ratios $S_{a}$ have been extracted from the data set of the aerosol types identified in the CALIOP Level 1.5. The reason why these values have not been taken directly from the EARLINET data set is that only a limited number of lidar ratios $S_{a}$ were available for the coincident measurements. In fact, this number is significantly reduced by the fact that a lidar needs to be equipped with a Raman channel for the independent extinction profile measurements, and these measurements are normally available only during night-time because of low signal-to-noise ratio (SNR) during daytime.

After calculating the terms $\alpha_{\mathrm{mol}}$ and $\alpha_{\mathrm{par}}$, the transmittance was derived using Eq. (5) and the EARLINET total attenuated backscatter profile was calculated using Eq. (2).

The methodology described in this section uses the CALIOP-derived information (lidar ratio $S_{a}$ ) for converting the EARLINET particle backscatter coefficient into total attenuated backscatter, so the EARLINET-derived products are not independent from CALIPSO ones.
In order to reduce the noise in the CALIOP signal (especially during daytime), the five profiles of the CALIOP total attenuated backscatter closest to the EARLINET station were averaged and then compared to the total attenuated backscatter of the EARLINET station. All of our CALIOP data points therefore correspond to spatial averages $100 \mathrm{~km}$ in length along the ground tracks, centred at the points of closest approach to the EARLINET stations.

To enable direct comparisons, the altitude scales of the EARLINET lidar profiles were adjusted to be the same as those of CALIOP (above mean sea level) at $60 \mathrm{~m}$ vertical spacing. In this way we obtained pairs of values at each altitude, referred to here as "data points", for each overpass.

In this work, the total attenuated backscatter for CALIOP $\left(\beta_{\text {att.CAL }}\right)$ and EARLINET $\left(\beta_{\text {att.EARL }}\right)$ is compared. In order to quantify the agreement between CALIOP and EARLINET measurements, the correlation coefficient, the mean bias, and the factor of exceedance are used (Kristiansen et al., 2012). Their defining equations are provided below.

The correlation coefficient $R$ is defined in the usual way as

$R=\frac{\sum_{i=1}^{N}\left(\beta_{\text {att.CAL }_{i}}-\overline{\beta_{\text {att.CAL }}}\right)\left(\beta_{\text {att.EAR }_{i}}-\overline{\beta_{\text {att.EAR }}}\right)}{\sqrt{\sum_{i=1}^{N}\left(\beta_{\text {att.CAL }_{i}}-\overline{\beta_{\text {att.CAL }}}\right)^{2} \sqrt{\sum_{i=1}^{N}\left(\beta_{\text {att.EAR }_{i}}-\overline{\beta_{\text {att.EAR }}}\right)^{2}}}}$.

$R$ shows the strength of a linear relationship between the CALIOP and EARLINET values. It ranges from -1 to +1 , where a value of -1 means a total negative correlation, +1 is a total positive correlation, and a value of 0 indicates no correlation.

The mean bias (MB) is defined as

$$
\begin{aligned}
& \mathrm{MB}=\frac{1}{N} \sum_{i=1}^{N}\left(\beta_{\mathrm{att} . C A L_{i}}-\beta_{\mathrm{att.EAR}_{i}}\right) \\
& \mathrm{MB}=\frac{1}{\mathrm{~N}} \sum_{\mathrm{i}=1}^{\mathrm{N}}\left(\beta_{\mathrm{att} \mathrm{CAL}}-\beta_{\mathrm{att} \mathrm{EAR}_{i}}\right) \\
& \mathrm{MB}=\frac{1}{N} \sum_{i=1}^{N}\left(\beta_{\text {att.CAL }_{i}}-\beta_{\text {att.EAR }_{i}}\right),
\end{aligned}
$$

where $N$ is the number of the data points in the height range where both CALIOP and EARLINET attenuated backscatter data are available.

The factor of exceedance $(\mathrm{FoE})$ is defined as

$\mathrm{FoE}=\left[\frac{N\left(\beta_{\text {att.CAL }}>\beta_{\text {att.EARL }}\right)}{N}-0.5\right]$,

where $N\left(\beta_{\text {att.CAL }}>\beta_{\text {att.EAR }}\right)$ is the number of data points in which CALIOP backscatter coefficient measurements are higher than the coincident EARLINET observations. The FoE value can vary between -0.5 (all CALIOP values are underestimated) and +0.5 (all CALIOP values are overestimated). 


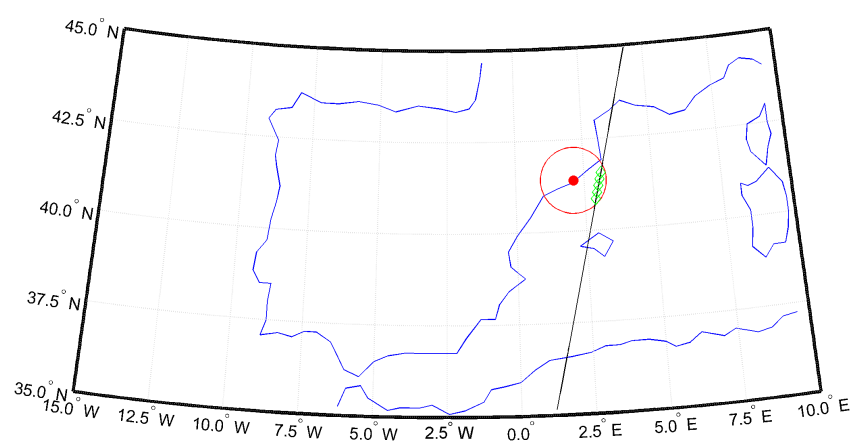

Figure 1. CALIOP overpass over Barcelona station on 20 September 2011 at 02:00 UTC at $77.9 \mathrm{~km}$ distance from the station. The red circle shows $100 \mathrm{~km}$ distance from the EARLINET station (the red dot in the centre). The black line represents the CALIOP ground track, while the green empty diamonds represent five CALIOP profiles that were averaged and compared to EARLINET measurements.

\section{Results}

\subsection{Case studies}

Two particular cases of CALIOP overpasses were chosen to demonstrate the methodology described in Sect. 2 and to show CALIOP's capability to detect aerosol layers under different conditions. CALIOP overpasses close to the Barcelona and Granada EARLINET stations are used in this illustration. The first overpass represents one of the best agreements between CALIOP and EARLINET stations out of 48 overpasses; the second overpass is an example of a case with discrepancies between the measurements by the two instruments.

The CALIOP overpass map for the first case study (Barcelona) is shown in Fig. 1. The attenuated CALIOP and EARLINET backscatter coefficients vs. altitude are shown in the left panel of Fig. 2. The aerosol type flag was assigned by the CALIOP aerosol classification algorithm (Liu et al., 2009), and it is presented in each case by different coloured dots in Fig. 2. The attenuated backscatter profiles agree well in the FT, and the PBL top was adequately distinguished by CALIOP (Fig. 2). The results show that the correlation between the two profiles is strong, with a correlation coefficient of 0.96 . The factor of exceedance equals 0.1 , which shows an overestimation of $60 \%$ of the CALIOP data points. For this case, the calculated mean bias value was $0.1 \mathrm{Mm}^{-1} \mathrm{sr}^{-1}$.

The second case study was carried out for a CALIOP overpass over the Granada EARLINET station (Fig. 3), and it represents a Saharan dust event, which stretched from the region of northwestern Africa over Gibraltar towards the southern part of Spain. The Hybrid Single-Particle Lagrangian Integrated Trajectory model (HYSPLIT) (Draxler and Rolph, 2013; Rolph et al., 2013) was used to analyse the origin of the air mass. The backward-trajectory analysis confirms that the air mass came from Africa, the Sahara region. The results of the analysis are shown in Fig. 4. The attenuated backscatter vs. altitude comparison is shown in the left panel of Fig. 5. A dust layer is detected between 4 and $6.5 \mathrm{~km}$ by both lidars; however, the CALIOP profile differs from the EARLINET profile at the higher altitudes by an amount outside the uncertainty bounds of the instruments. There are some additional discrepancies between CALIOP and EARLINET measurements (left panel of Fig. 5). The top of the CALIOP-detected dust layer is approximately $500 \mathrm{~m}$ higher. There were two distinguishable aerosol layers in the EARLINET backscatter profile, namely the primary one between 5 and $6 \mathrm{~km}$ altitude and a secondary one around $2 \mathrm{~km}$ altitude. However, the secondary layer in the PBL region is barely distinguishable in the CALIOP profile.

Those differences between two profiles could happen for a few reasons. Since Granada is located in a valley, the temperature inversion is a pretty usual phenomenon there. The inversion could trap the pollutants that form near ground level. It is worth mentioning also that both measurements were separated by a distance of $67 \mathrm{~km}$ with the Sierra Nevada (elevation $3.5 \mathrm{~km}$ ) between the station and the CALIOP track. As a result, all earlier-mentioned circumstances (the mountains, the temperature inversion and the distance) could limit the CALIOP's abilities to detect the local pollution within the PBL. In contrast, this local pollution event was successfully detected by the EARLINET station in the valley. Another reason for the discrepancy could be an invalid CALIOP aerosol type classification. However for this specific case, CALIOP detected the layer as a dust layer and the lidar ratio $S_{a}$ provided in the EARLINET file was equal to 55 (dust). That eliminates the possibility of invalid type classification for this case. It is likely that local topographic location combined with trapped local pollutants during the summer period (e.g. smog) negatively influenced the agreement between the CALIOP and EARLINET measurements. As a result, the correlation between two profiles is not as strong as in the first case, during which no obvious obstacles were present between the Barcelona EARLINET station and the CALIOP track over the Mediterranean Sea. Thus for the second case, the correlation coefficient was 0.47 while the mean bias was $-0.09 \mathrm{Mm}^{-1} \mathrm{sr}^{-1}$. Consequently, the factor of exceedance was -0.15 , which shows that $65 \%$ of the CALIOP total attenuated backscatter values were lower than EARLINET values.

The next section provides an overview of the agreement between CALIOP and EARLINET attenuated backscatter values for all of the CALIOP overpasses with ground track offset distances of $100 \mathrm{~km}$ or less.

\subsection{EARLINET-CALIOP comparison with ground track distance $100 \mathrm{~km}$}

From November 2010 to December 2012, 48 CALIOP overpasses occurred within a $100 \mathrm{~km}$ distance from an oper- 

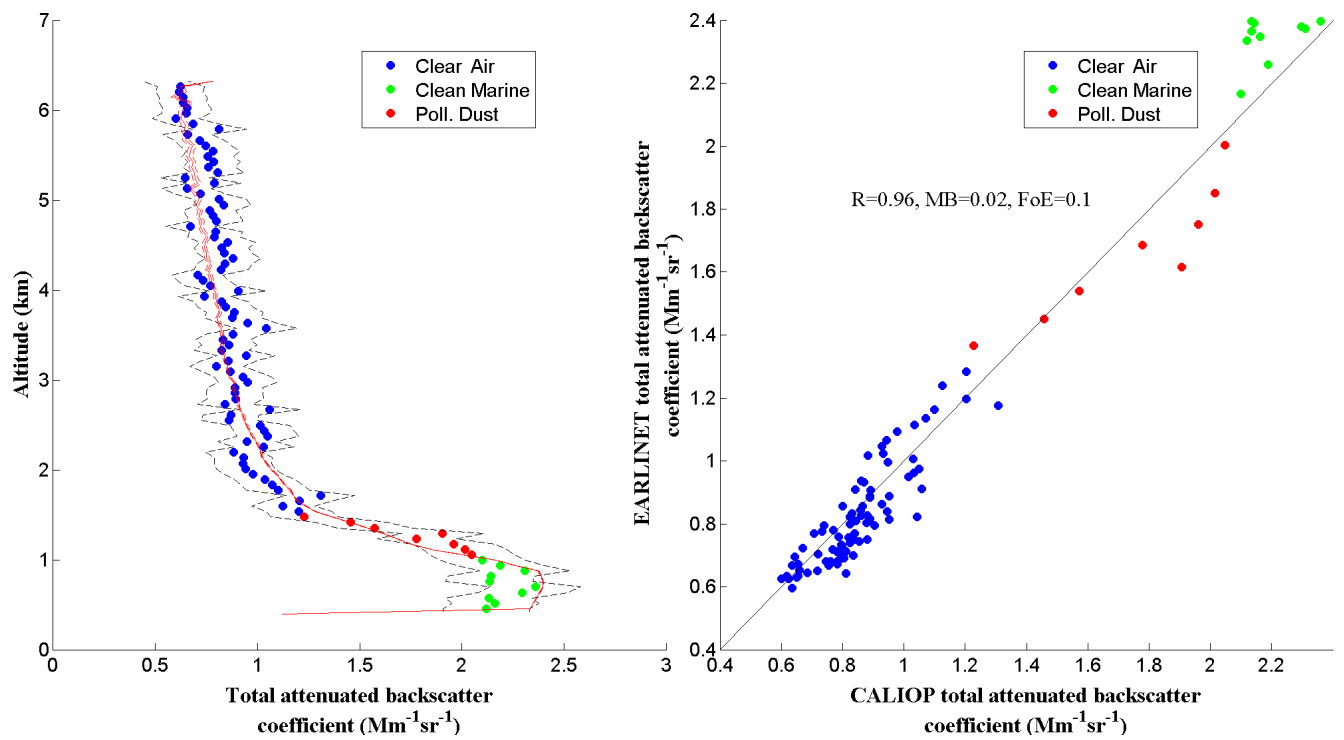

Figure 2. Left panel: attenuated backscatter versus altitude for a CALIOP overpass at Barcelona station on 20 September 2011 at 02:00 UTC at $77.9 \mathrm{~km}$ distance from the station (the red line shows the EARLINET attenuated backscatter profile, the red dashed lines show EARLINET uncertainties, the dots represent CALIOP data, and the black dashed lines show the CALIOP uncertainties); right panel: corresponding scatter plot of CALIOP attenuated backscatter (different colours represent different detected aerosol type; see legend) against EARLINET attenuated backscatter with a $1: 1$ reference line (black).

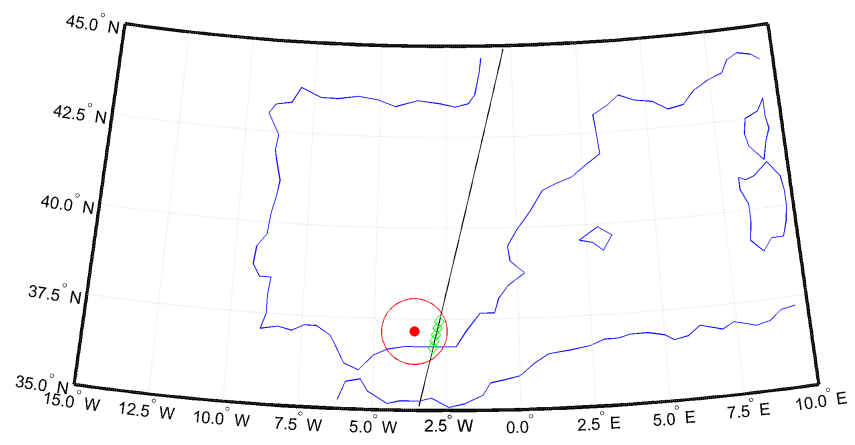

Figure 3. CALIOP overpass over Granada station on 7 July 2011 at 02:20 UTC at $67 \mathrm{~km}$ distance from the station. The red circle shows $100 \mathrm{~km}$ distance from EARLINET station (the red dot in the centre). The black line represents the CALIOP ground track, while the green empty diamonds represent five CALIOP profiles that were averaged and compared to EARLINET measurements.

ating EARLINET station, with aerosol layers classified as dust, polluted dust, clean marine, clean continental, polluted continental, mixed and/or smoke/biomass burning. These 48 overpasses resulted in 7405 data points that were deemed valid for evaluation against EARLINET. The scatter plot of CALIOP and EARLINET attenuated backscatter values for all of these data points is shown in Fig. 6.

The CALIOP and EARLINET data correlate well $(R=$ 0.86 ), with a mean bias equal to $0.03 \mathrm{Mm}^{-1} \mathrm{sr}^{-1}$, while the factor of exceedance value is 0.17 . The latter statistical parameter indicates that $67 \%$ of the CALIOP attenu- ated backscatter values were higher than the corresponding EARLINET measurements. However, there were several points that deviated from the $1: 1$ line. In order to investigate the cause of these outliers, the data were colour-coded by the overpass distance (Fig. 6) and the vertical height of the aerosol layer (Fig. 7), which revealed that the majority of the outliers were observed when the distance between the EARLINET station and CALIPSO overpass exceeded $30 \mathrm{~km}$. Moreover, the correlation seemed to be dependent on the height of the aerosol layer, where the larger discrepancies are observed for low altitudes. This is also in agreement with Mona et al. (2009) and Pappalardo et al. (2010). Furthermore, the correlation seemed to be dependent also on the presence of multiple layers in the FT and the PBL at the same time (as in the second case study). Therefore, further analysis was performed for the PBL and the FT separately.

\subsubsection{PBL and FT with ground track distance $100 \mathrm{~km}$}

The PBL height was assumed to always be $2.5 \mathrm{~km}$ for this analysis (Mattis et al., 2004; Pappalardo et al., 2004). The scatter plots for the separated PBL and FT data sets are shown in Figs. 8 and 9 and characterized by $R, \mathrm{MB}$ and $\mathrm{FoE}$ parameters (Table 2).

The correlation is significantly stronger for the FT $(R=$ $0.85)$ compared to the PBL $(R=0.60)$. The factor of exceedance for the FT equals 0.22 , which indicates that $72 \%$ of the CALIOP total attenuated backscatter values were higher than the EARLINET values, with a mean bias of $0.06 \mathrm{Mm}^{-1} \mathrm{sr}^{-1}$. Correspondingly, the FoE for the PBL was 
NOAA HYSPLIT MODEL

Backward trajectories ending at 0200 UTC 07 Jul 11 GDAS Meteorological Data

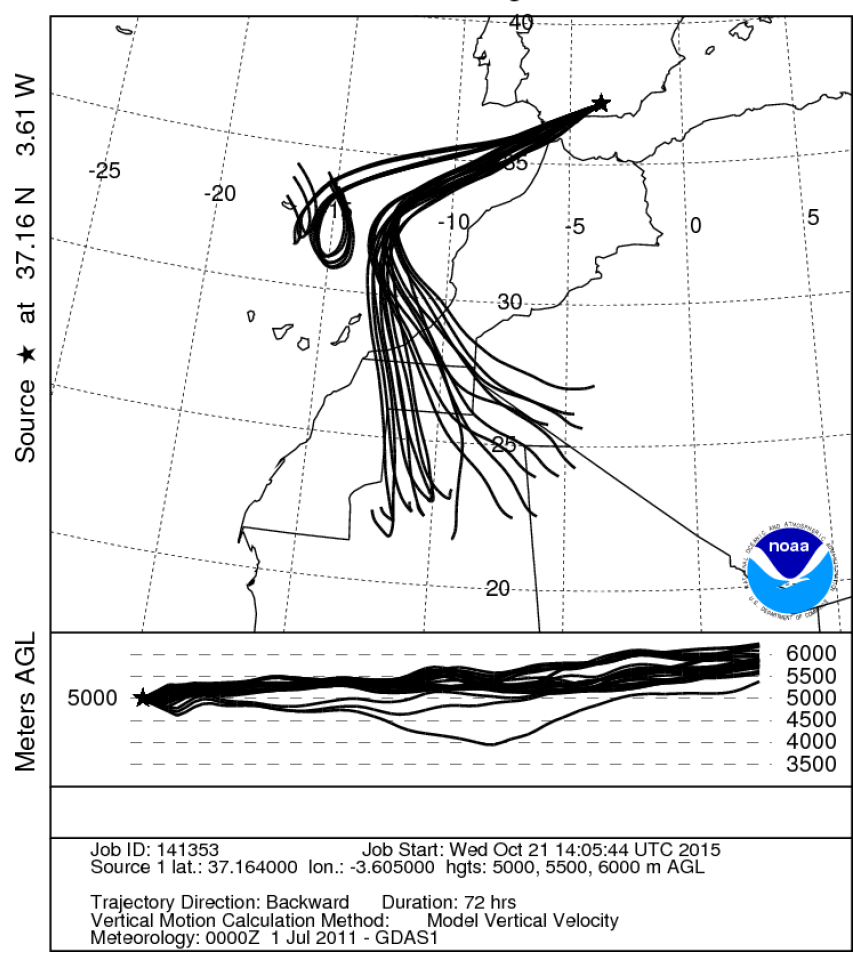

Figure 4. HYSPLIT backward trajectories for the overpass over the EARLINET station in Granada on 7 July 2011 at 02:00 UTC confirm that the air mass came from the region of northwestern Africa, over Gibraltar, and towards the southern part of Spain.

Table 1. EARLINET stations that had coincident measurements with CALIOP during the observational period (Pappalardo et al., 2014).

\begin{tabular}{rlll}
\hline No. & $\begin{array}{l}\text { Station } \\
\text { code }\end{array}$ & $\begin{array}{l}\text { Station name, } \\
\text { location }\end{array}$ & Coordinates \\
\hline 1 & at & Athens, Greece & $37.96^{\circ} \mathrm{N}, 23.78^{\circ} \mathrm{E}$ \\
2 & ba & Barcelona, Spain & $41.389^{\circ} \mathrm{N}, 2.112^{\circ} \mathrm{E}$ \\
3 & be & Belsk, Poland & $51.84^{\circ} \mathrm{N}, 20.79^{\circ} \mathrm{E}$ \\
4 & bu & Bucharest, Romania & $44.348^{\circ} \mathrm{N}, 26.029^{\circ} \mathrm{E}$ \\
5 & ca & Cabauw, Netherlands & $51.97^{\circ} \mathrm{N}, 4.93^{\circ} \mathrm{E}$ \\
6 & ev & Evora, Portugal & $38.568^{\circ} \mathrm{N}, 7.912^{\circ} \mathrm{W}$ \\
7 & gr & Granada, Spain & $37.164^{\circ} \mathrm{N}, 3.605^{\circ} \mathrm{W}$ \\
8 & hh & Hamburg, Germany & $53.568^{\circ} \mathrm{N}, 9.973^{\circ} \mathrm{E}$ \\
9 & is & Ispra, Italy & $45.811^{\circ} \mathrm{N}, 8.621^{\circ} \mathrm{E}$ \\
10 & ma & Madrid, Spain & $40.456^{\circ} \mathrm{N}, 3.726^{\circ} \mathrm{W}$ \\
11 & ms & Maisach, Germany & $48.209^{\circ} \mathrm{N}, 11.258^{\circ} \mathrm{E}$ \\
12 & na & Napoli, Italy & $40.838^{\circ} \mathrm{N}, 14.183^{\circ} \mathrm{E}$ \\
13 & pl & Palaiseau, France & $48.7^{\circ} \mathrm{N}, 2.2^{\circ} \mathrm{E}$ \\
14 & po & Potenza, Italy & $40.601^{\circ} \mathrm{N}, 15.724^{\circ} \mathrm{E}$ \\
\hline & & &
\end{tabular}

Table 2. Statistics of CALIOP and EARLINET agreement within the PBL and the FT with ground track distance within $100 \mathrm{~km}$.

\begin{tabular}{lcrr}
\hline Region & $R$ & $\begin{array}{r}\mathrm{MB} \\
\left(\mathrm{Mm}^{-1} \mathrm{sr}^{-1}\right)\end{array}$ & FoE \\
\hline Entire range & 0.86 & 0.03 & 0.17 \\
PBL & 0.60 & -0.14 & -0.12 \\
FT & 0.85 & 0.06 & 0.22 \\
\hline
\end{tabular}

Table 3. Statistics of CALIOP and EARLINET agreement within the PBL and the FT using data filtering.

\begin{tabular}{lrrr}
\hline Region & $R$ & $\begin{array}{r}\mathrm{MB} \\
\left(\mathrm{Mm}^{-1} \mathrm{sr}^{-1}\right)\end{array}$ & FoE \\
\hline Entire range & 0.84 & 0.01 & 0.08 \\
PBL & 0.65 & -0.09 & -0.09 \\
FT & 0.79 & 0.03 & 0.11 \\
\hline
\end{tabular}

equal to -0.12 and $\mathrm{MB}=-0.14 \mathrm{Mm}^{-1} \mathrm{sr}^{-1}$, which suggests that only $38 \%$ of CALIOP values were higher than EARLINET values in the PBL.

The aerosol layers in the free troposphere are often characterized by smaller horizontal variability compared to the PBL; it is thus likely that a higher EARLINET-CALIOP correlation can occur in the FT. On the other hand, the boundary layer, especially during convective periods, undergoes higher temporal and spatial variability due to continuous PBL updraft and FT downdraft. That could influence lower correlation between CALIOP and EARLINET in the PBL. Moreover, when an aerosol layer occurs in the FT, it attenuates the CALIOP lidar signal, which will have less energy to penetrate further down into the PBL. To investigate that idea, data filtering with threshold values from the second case study were used. However, this choice reduced the amount of CALIOP overpasses from 48 down to 27 , while the number of data points available for the comparison dropped from 7405 down to 3398 .

\subsubsection{Filtered PBL and FT with ground track distance of $100 \mathrm{~km}$}

In this analysis, the data points were selected from the CALIOP overpasses based on threshold values of the column backscatter coefficient (vertically summed values). These values were derived from the second case study (with aerosol layer occurring in the FT above the PBL) in two chosen altitudes ranges (up to $3 \mathrm{~km}$ and above $3 \mathrm{~km}$ ). The threshold column backscatter value for the altitude range up to $3 \mathrm{~km}$ was $38 \mathrm{Mm}^{-1} \mathrm{sr}^{-1}$, while the value above $3 \mathrm{~km}$ was $71 \mathrm{Mm}^{-1} \mathrm{sr}^{-1}$. Next, only CALIOP overpasses with detected aerosol values lower than these threshold values were used in the analysis. After applying such filtering, the statistics are presented in Table 3. 

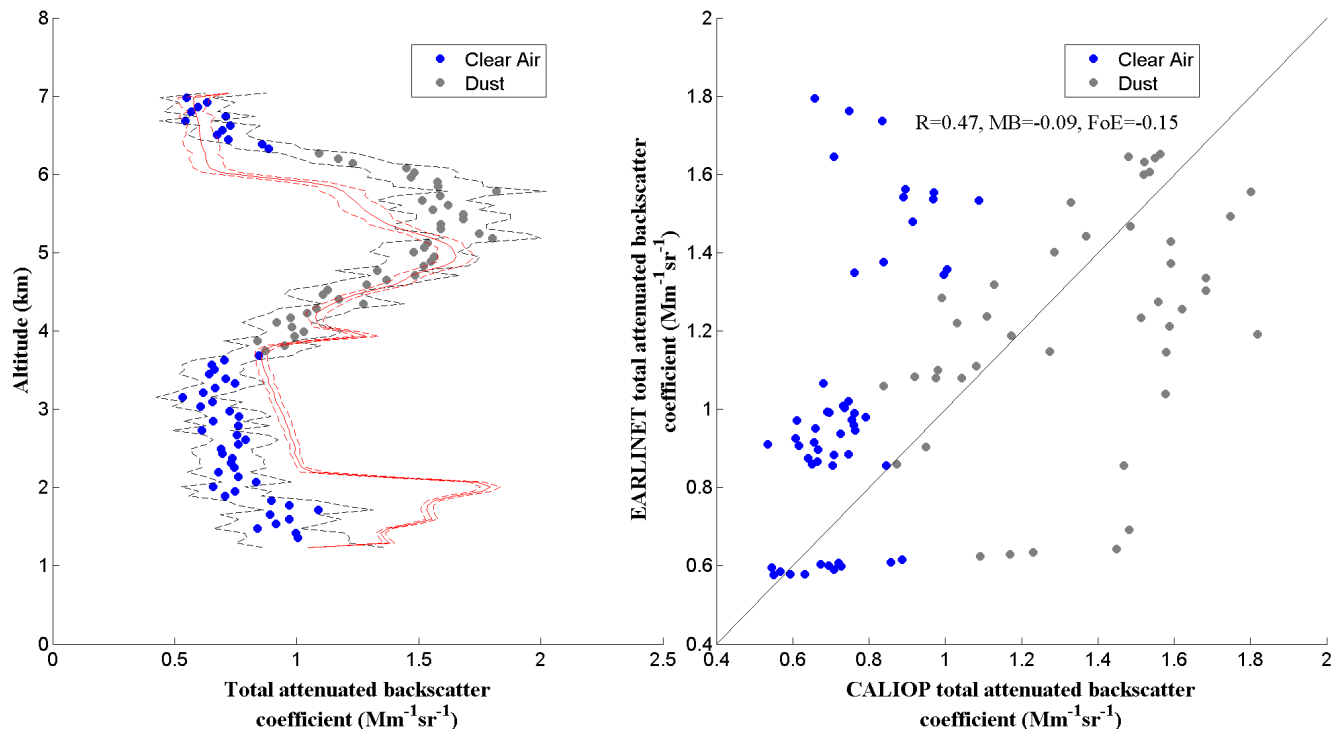

Figure 5. Left panel: Attenuated backscatter versus altitude for a CALIOP overpass over Granada station on 7 July 2011 at 02:20 UTC at $67 \mathrm{~km}$ distance from the station (the red line shows the EARLINET attenuated backscatter profile, the red dashed lines show EARLINET uncertainties, the dots represent CALIOP data, and the dashed lines show the CALIOP uncertainty); right panel: corresponding scatter plot of CALIOP attenuated backscatter (different colours represent different detected aerosol; see legend) against EARLINET attenuated backscatter, with a $1: 1$ reference line (black).

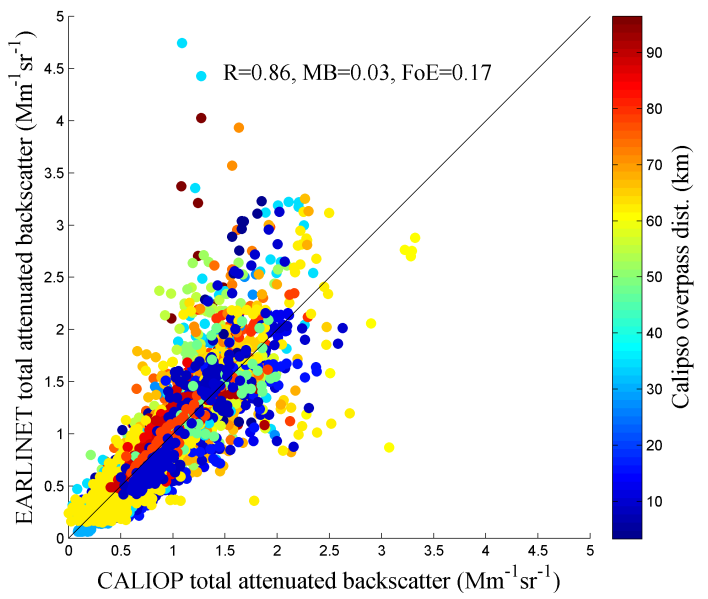

Figure 6. CALIOP vs EARLINET total attenuated backscatter for CALIOP overpasses over EARLINET stations within $100 \mathrm{~km}$ ground track offset distance. The colour scale shows the ground track distance from the EARLINET station.

The scatter plots of the attenuated backscatter for CALIOP and EARLINET after applying this data filtering are presented in Figs. 10 and 11. The correlation between the two sets of attenuated backscatter measurements became marginally stronger in the PBL $(R=0.65)$, while the same parameter for the FT decreased from $R=0.85$ to $R=$ 0.79. Correspondingly, the other statistical parameters improved for the PBL $(\mathrm{MB}=-0.09$ and $\mathrm{FoE}=-0.09)$, but they decreased by a factor of 2 for the FT $(\mathrm{MB}=0.03$ and

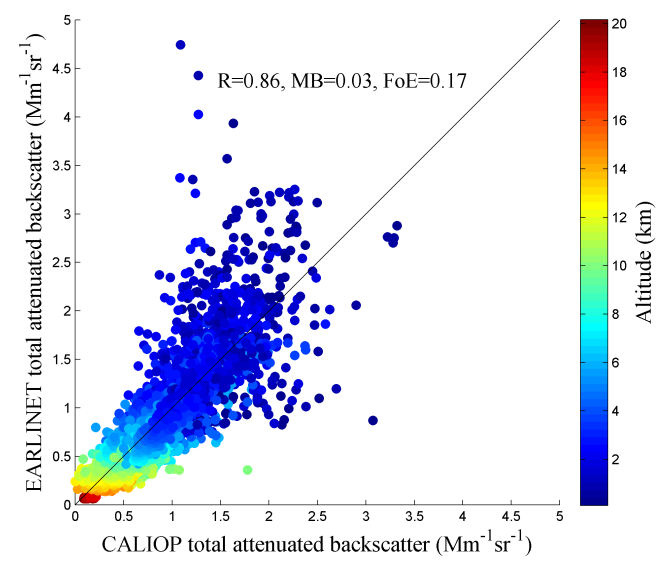

Figure 7. CALIOP vs. EARLINET total attenuated backscatter for CALIOP overpasses over EARLINET station points within $100 \mathrm{~km}$ ground track distance, with colour coding showing the aerosol layer altitude.

$\mathrm{FoE}=0.11)$. This suggests considerable variability, across the data set, in the spatial distribution of the aerosol over spatial scales of $100 \mathrm{~km}$ or less around some EARLINET stations rather than influence from elevated FT layers.

The clean marine type of aerosol was detected by CALIOP exclusively in the PBL (Fig. 12b), which is consistent with the marine surface source. However, a negative correlation coefficient was found for this aerosol type. One data point looks like an outlier. If this data point is removed, the statis- 


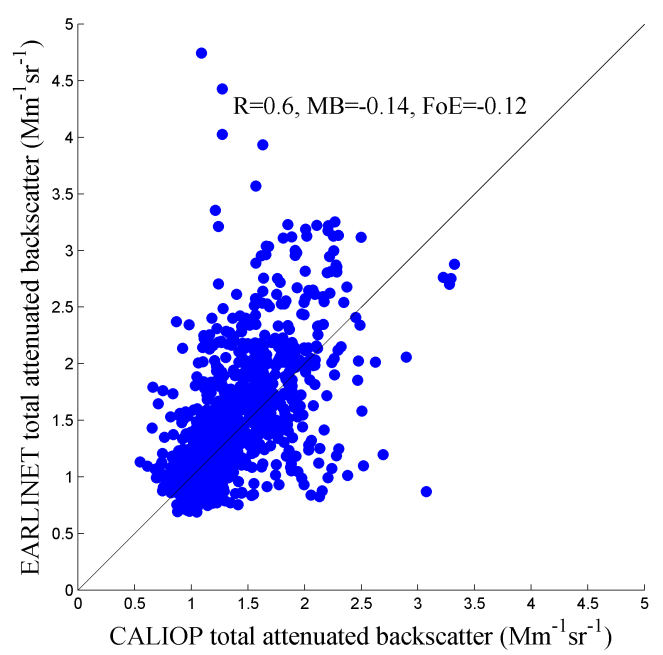

Figure 8. CALIOP vs EARLINET total attenuated backscatter for CALIOP overpasses over EARLINET stations for the PBL only, within $100 \mathrm{~km}$ ground track distance.

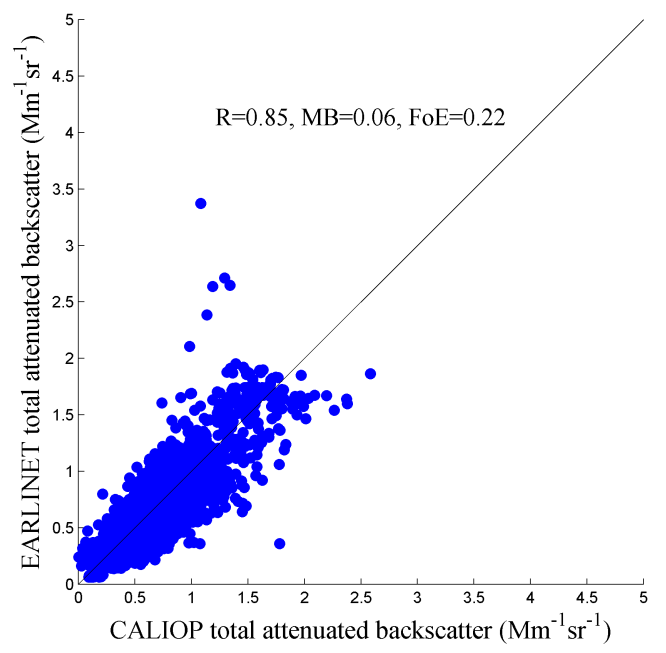

Figure 9. CALIOP vs. EARLINET total attenuated backscatter for CALIOP overpasses over EARLINET stations for the FT only, within $100 \mathrm{~km}$ ground track distance.

tics for the clean marine aerosol type become the following: $R=0.96, \mathrm{MB}=0$, and $\mathrm{FoE}=0.01$.

The dust aerosol is usually transported over long distances in the FT (Fig. 13b), where its correlation is stronger $(R=0.57)$ compared to the PBL $(R=0.46$, Fig. $12 \mathrm{c})$, because the PBL aerosol is more affected by local sources.

The polluted dust aerosol detected by CALIOP represents a mix of dust and biomass burning/smoke aerosol. Both types of aerosol contribute to trans-boundary air pollution and are transported in the FT. However, the correlation coefficient for polluted dust aerosol is higher in the PBL $(R=0.44)$ than in the FT $(R=0.38)$ (Figs. 12d and 13c).

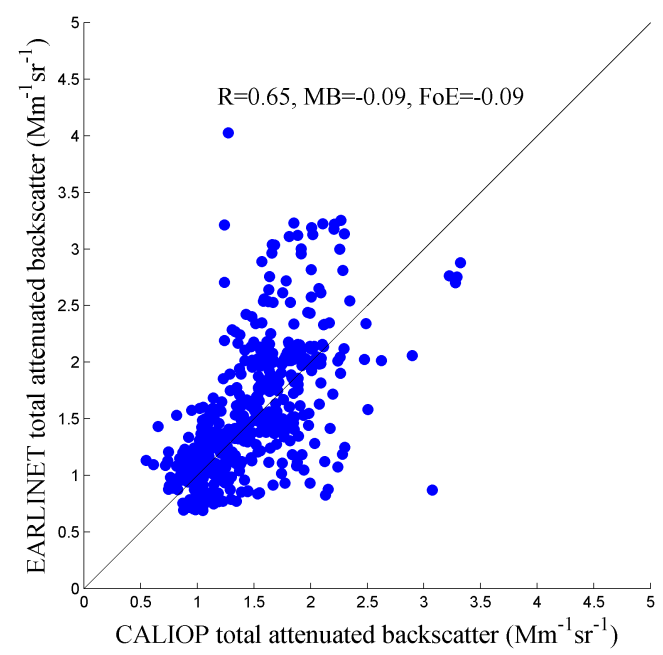

Figure 10. CALIOP vs. EARLINET total attenuated backscatter for CALIOP overpasses over EARLINET stations only for PBL. The plot includes all data points for overpasses without layers present in both the PBL and the FT.

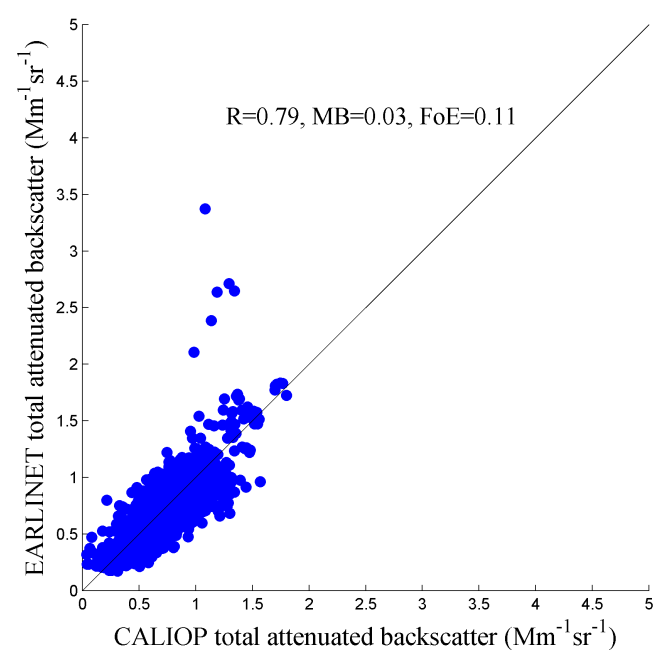

Figure 11. CALIOP vs. EARLINET total attenuated backscatter for CALIOP overpasses over EARLINET stations within $100 \mathrm{~km}$ overpass distance only for FT. The plot includes all data points for overpasses without present layers present in both the the PBL and the FT.

On the other hand, the polluted continental aerosol originates from local sources, which is consistent with the fact that CALIOP detected this type exclusively in the PBL (Fig. 12e); however, this localisation affected CALIOP's ability to represent the variations of the polluted aerosol, because significant spatial averaging is required to obtain adequate SNR. Strong local sources could result in higher temporal and spatial variability in the PBL. Therefore, a poorer correlation $(R=0.37)$ between CALIOP and EARLINET could be a result of different area coverage for the two methods. 

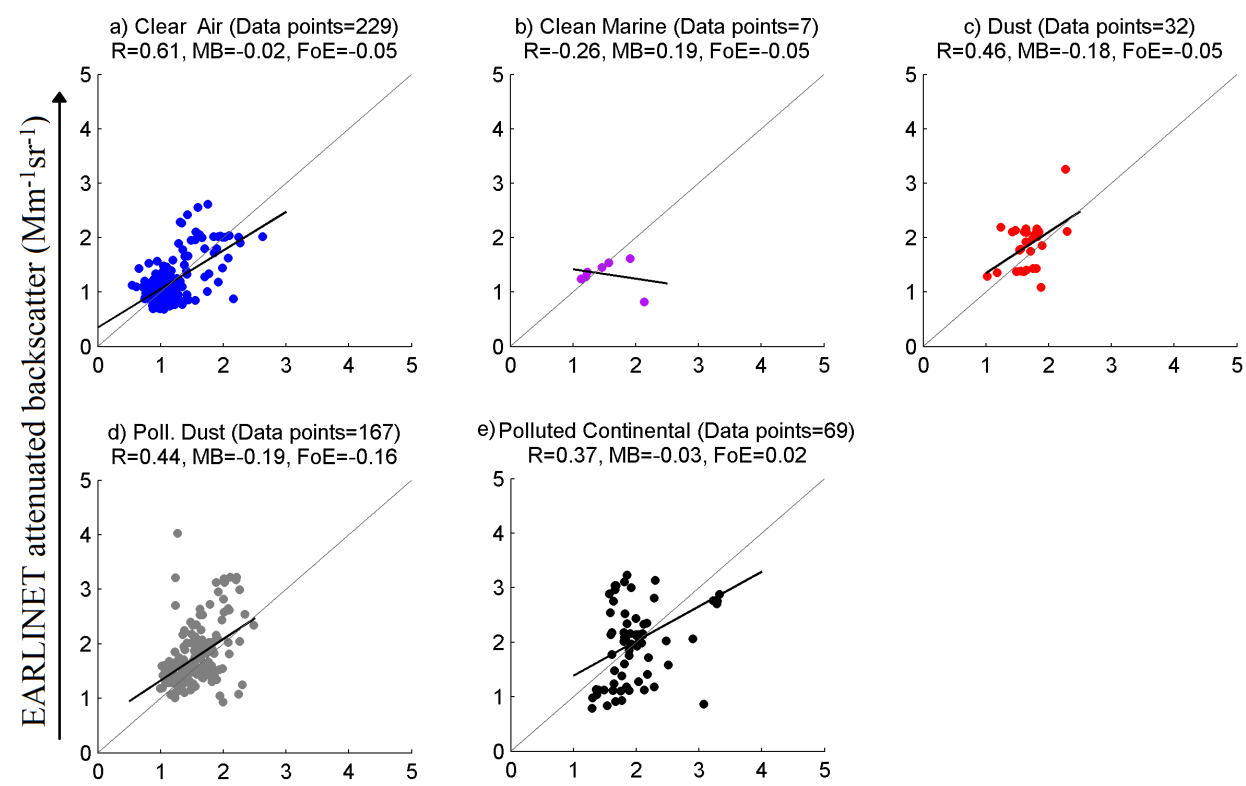

\section{CALIOP total attenuated backscatter $\left(\mathrm{Mm}^{-1} \mathrm{sr}^{-1}\right)$}

Figure 12. Five Level 1.5 feature types for CALIOP overpasses over EARLINET stations for the PBL. The plot includes filtered data points for overpasses without layers present in both the PBL and the FT.

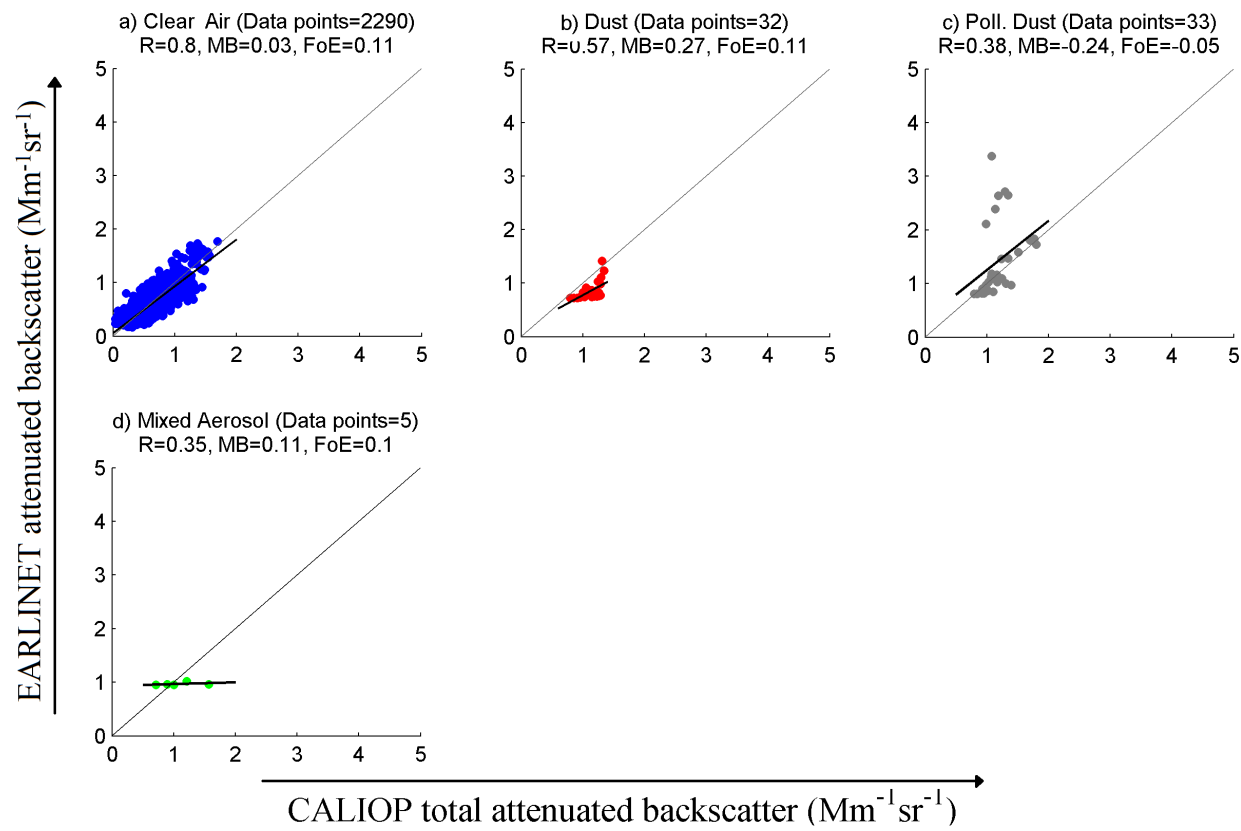

Figure 13. Four Level 1.5 feature types for CALIOP overpasses over EARLINET stations for the FT. The plot includes filtered data points for overpasses without layers present in both the PBL and the FT.

The mixed aerosol (Fig. 13d) was detected only in FT cases, with the lowest $R=0.35$ value across all aerosol types. The reason for this is that it is a mix of other aerosol types, which causes a low value of the correlation coefficient.
The technique of data filtering allowed improving the agreement between different aerosol types, but at the same time the improvements were not very significant. 


\section{Conclusions}

Over 3 years, 48 CALIOP overpasses occurred within a $100 \mathrm{~km}$ ground track offset distance from an operating EARLINET station, resulting in 7405 data points for the analysis presented here. The inter-comparison of the total attenuated backscatter profiles from near-real-time CALIOP Level 1.5 data and converted EARLINET data showed fairly good agreement, with the correlation around 0.86 , a mean bias of $0.03 \mathrm{Mm}^{-1} \mathrm{sr}^{-1}$ and a factor of exceedance of 0.17 . On average, the CALIOP attenuated backscatter values were slightly higher (by $3 \%$ ) than the EARLINET values.

While it was suspected that the presence of highconcentration layers in the FT affected the agreement between CALIOP and EARLINET, after filtering out these cases with notable FT aerosol layers, no real improvement in the correlation coefficient was observed. This suggest that the lack of a high correlation between the data sets is more likely due to variability in the distribution of aerosols across the $100 \mathrm{~km}$ area selected around the EALRINET stations. Before applying the filtering, the CALIOP attenuated backscatter values were lower by $20 \%$ in the PBL compared to the EARLINET measurements; however, they were higher by $8 \%$ in the FT. After applying the filtering, the correlation coefficient improved (from $R=0.60$ up to $R=0.65$ ) within the PBL, and the mean bias decreased from $\mathrm{MB}=-0.14 \mathrm{Mm}^{-1} \mathrm{sr}^{-1}$ down to $\mathrm{MB}=-0.09 \mathrm{Mm}^{-1} \mathrm{sr}^{-1}$. The factor of exceedance decreased as well, from $\mathrm{FoE}=-0.12$ to $\mathrm{FoE}=-0.09$. Finally, the majority of the outliers in the regression plot of CALIOP and EARLINET attenuated backscatter were shown to be caused by the presence of layers in both the PBL and the FT.

The aerosol types detected by CALIOP were consistent with the source of the aerosol and the transport mechanism. Aerosols from local sources were mainly detected in the boundary layer, while long-range transport pollution was observed in the FT. The correlation for different aerosol types was stronger within the FT; it was in the range of 0.35 to 0.80 , with mean bias values of -0.24 to $0.27 \mathrm{Mm}^{-1} \mathrm{sr}^{-1}$, and the factor of exceedance between -0.05 and 0.11 . The correlation for the PBL was slightly weaker $(R=0.37-$ $0.61)$; the mean bias values were in the range of -0.19 to $0.19 \mathrm{Mm}^{-1} \mathrm{sr}^{-1}$, with the factor of exceedance -0.16 to 0.02 .

Acknowledgements. The authors gratefully acknowledge the European Union for funding this work under the 7th Framework Programme as the MACC-II subproject, and the Irish Research Council "New Foundations" programme. The authors acknowledge the CALIPSO scientific team for granting access to the CALIOP Level 1.5 data and EARLINET for providing aerosol lidar profiles, which were available from the EARLINET webpage. The authors also acknowledge the NOAA Air Resources Laboratory (ARL) for the provision of the HYSPLIT transport and dispersion model used in this study.
Edited by: R. Engelen

\section{References}

Bösenberg, J., Matthias, V., Amodeo, A., Amoiridis, V., Ansmann, A., Baldasano, J. M., Balin, I., Balis, D., Böckmann, C., Boselli, A., Carlsson, G., Chaikovsky, A., Chourdakis, G., Comerón, A., De Tomasi, F., Eixmann, R., Freudenthaler, V., Giehl, H., Grigorov, I., Hågård, A., Iarlori, M., Kirsche, A., Kolarov, G., Komguem, L., Kreipl, S., Kumpf, W., Larchevêque, G., Linné, H., Matthey, R., Mattis, I., Mekler, A., Mironova, I., Mitev, V., Mona, L., Müller, D., Music, S., Nickovic, S., Pandolfi, M., Papayannis, A., Pappalardo, G., Pelon, J., Pérez, C., Perrone, R. M., Persson, R., Resendes, D. P., Rizi, V., Rocadenbosch, F., Rodrigues, J. A., Sauvage, L., Schneidenbach, L., Schumacher, R., Shcherbakov, V., Simeonov, V., Sobolewski, P., Spinelli, N., Stachlewska, I., Stoyanov, D., Trickl, T., Tsaknakis, G., Vaughan, G., Wandinger, U., Wang, X., Wiegner, M., Zavrtanik, M., and Zerefos, C.: EARLINET: a European Aerosol Research Lidar Network to Establish an Aerosol Climatology, Max-Planck-Institut Report No. 348, Hamburg, Germany, 2003.

Bucholtz, A.: Rayleigh-scattering calculations for the terrestrial atmosphere, Appl. Optics, 34, 2765-2773, doi:10.1364/AO.34.002765, 1995.

Burton, S. P., Ferrare, R. A., Vaughan, M. A., Omar, A. H., Rogers, R. R., Hostetler, C. A., and Hair, J. W.: Aerosol classification from airborne HSRL and comparisons with the CALIPSO vertical feature mask, Atmos. Meas. Tech., 6, 13971412, doi:10.5194/amt-6-1397-2013, 2013.

CALIPSO Quality Statements: CALIPSO Quality Statements Lidar Level 1.5 Data Product Version Release: 3.02, available at: https://eosweb.larc.nasa.gov/sites/default/files/project/ calipso/quality_summaries/CAL_lidar_L1-5_v3-02.pdf (last access: 15 December 2014), 2011.

Draxler, R. R. and Rolph, G. D.: HYSPLIT (HYbrid Single-Particle Lagrangian Integrated Trajectory) Model access via NOAA ARL READY Website, available at: http://www.arl.noaa.gov/ HYSPLIT.php (last access: 15 December 2014), 2013.

Giannakaki, E., Balis, D. S., Amiridis, V., and Zerefos, C.: Optical properties of different aerosol types: seven years of combined Raman-elastic backscatter lidar measurements in Thessaloniki, Greece, Atmos. Meas. Tech., 3, 569-578, doi:10.5194/amt-3569-2010, 2010.

Groß, S., Gasteiger, J., Freudenthaler, V., Schnell, F. and Wiegner, M.: Characterization of the Eyjafjallajökull ash-plume by means of lidar measurements over the Munich EARLINET-site, Proc. SPIE, 7832, 78320M-78320M-8, 2010.

Haywood, J., Francis, P., Dubovik, O., Glew, M. and Holben, B.: Comparison of aerosol size distributions, radiative properties, and optical depths determined by aircraft observations and Sun photometers during SAFARI 2000, J. Geophys. Res.-Atmos., 108, 8471, doi:10.1029/2002JD002250, 2003.

Kristiansen, N. I., Stohl, A., Prata, A. J., Bukowiecki, N., Dacre, H., Eckhardt, S., Henne, S., Hort, M. C., Johnson, B. T., Marenco, F., Neininger, B., Reitebuch, O., Seibert, P., Thomson, D. J., Webster, H. N. and Weinzierl, B.: Performance assessment of a volcanic ash transport model mini-ensemble used for inverse 
modeling of the 2010 Eyjafjallajökull eruption: Eyjafjallajökull ash transport modeling, J. Geophys. Res.-Atmos., 117, D00U11, doi:10.1029/2011JD016844, 2012.

Liu, Z., Vaughan, M., Winker, D., Kittaka, C., Getzewich, B., Kuehn, R., Omar, A., Powell, K., Trepte, C., and Hostetler, C.: The CALIPSO lidar cloud and aerosol discrimination: version 2 algorithm and initial assessment of performance, J. Atmos. Ocean. Tech., 26, 1198-1213, doi:10.1175/2009JTECHA1229.1, 2009.

Lolli, S., Welton, E., Benedetti, A., Jones, L., Suttie, M., and Wang, S.: MPLNET lidar data assimilation in the ECMWF MACC-II Aerosol system: evaluation of model performances at NCU lidar station, in: Proceedings of SPIE - Lidar Technologies, Techniques, and Measurements for Atmospheric Remote Sensing X, Vol. 9246, doi:10.1117/12.2068201, 2014.

Mamouri, R. E., Amiridis, V., Papayannis, A., Giannakaki, E., Tsaknakis, G., and Balis, D. S.: Validation of CALIPSO spaceborne-derived attenuated backscatter coefficient profiles using a ground-based lidar in Athens, Greece, Atmos. Meas. Tech., 2, 513-522, doi:10.5194/amt-2-513-2009, 2009.

Mattis, I., Ansmann, A., Müller, D., Wandinger, U., and Althausen, D.: Multiyear aerosol observations with dual-wavelength Raman lidar in the framework of EARLINET, J. Geophys. Res.-Atmos., 109, D13203, doi:10.1029/2004JD004600, 2004.

Mattis, I., Mona, L., Müller, D., Pappalardo, G., Arboledas, L. A., Da'Mico, G., Amodeo, A., Apituley, A., Baldasano, J. M., Böckmann, C., Bösenberg, J., Chaikovsky, A., Comeron, A., Giannakaki, E., Grigorov, I., Rascado, J. L. G., Gustafsson, O., Iarlori, M., Linné, H., Mitev, V., Francisco Molero Menéndez, D. N., Nicolae, D., Papayannis, A., García-Pando, C. P., Perrone, M. R., Pietruczuk, A., Putaud, J.-P., Ravetta, F., Rodríguez, A., Seifert, P., Sicard, M., Simeonov, V., Sobolewski, P., Spinelli, N., Stebel, K., Stohl, A., Tesche, M., Trickl, T., Wang, X., and Wiegner, M.: EARLINET correlative measurements for CALIPSO, in: Proceedings of SPIE - The International Society for Optical Engineering, Vol. 6750, doi:10.1117/12.738090, 2007.

Mattis, I., Müller, D., Ansmann, A., Wandinger, U., Preißler, J., Seifert, P., and Tesche, M.: Ten years of multiwavelength Raman lidar observations of free-tropospheric aerosol layers over central Europe: geometrical properties and annual cycle, J. Geophys. Res.-Atmos., 113, D20202, doi:10.1029/2007JD009636, 2008.

Molero, F. and Pujadas, M.: Comparison of correlative measurements of CALIPSO lidar and the \#21 EARLINET station (CIEMAT-Madrid), in: Proceedings of SPIE - The International Society for Optical Engineering, Vol. 7111, doi:10.1117/12.799745, 2008.

Mona, L., Pappalardo, G., Amodeo, A., D’Amico, G., Madonna, F., Boselli, A., Giunta, A., Russo, F., and Cuomo, V.: One year of CNR-IMAA multi-wavelength Raman lidar measurements in coincidence with CALIPSO overpasses: Level 1 products comparison, Atmos. Chem. Phys., 9, 7213-7228, doi:10.5194/acp-97213-2009, 2009.

Omar, A. H., Winker, D. M., Vaughan, M. A., Hu, Y., Trepte, C. R., Ferrare, R. A., Lee, K.-P., Hostetler, C. A., Kittaka, C., Rogers, R. R., Kuehn, R. E., and Liu, Z.: The CALIPSO automated aerosol classification and lidar ratio selection algorithm, J. Atmos. Ocean. Tech., 26, 1994-2014, doi:10.1175/2009JTECHA1231.1, 2009.
Papayannis, A., Chourdakis, G., Tsaknakis, G., and Serafetinides, A.: One-year observations of the vertical structure of Saharan dust over Athens, Greece monitored by NTUA's lidar system in the frame of EARLINET, in: Proceedings of SPIE - The International Society for Optical Engineering, Vol. 4539, 146-157, doi:10.1117/12.454434, 2002.

Pappalardo, G., Amodeo, A., Mona, L., Pandolfi, M., Pergola, N., and Cuomo, V.: Raman lidar observations of aerosol emitted during the 2002 Etna eruption, Geophys. Res. Lett., 31, L05120, doi:10.1029/2003GL019073, 2004.

Pappalardo, G., Mona, L., Wandinger, U., Mattis, I., Amodeo, A., Ansmann, A., Apituley, A., Alados-Arboledas, L., Balis, D., Chaikovsky, A., Comeron, A., D’Amico, G., Freudenthaler, V., Giunta, A., Grigorov, I., Hiebsch, A., Linnè, H., Madonna, F., Papayannis, A., Perrone, M. R., Pietruczuk, A., Pujadas, M., Rizi, V., Spinelli, N., and Wiegner, M.: Analysis of the EARLINET correlative measurements for CALIPSO, Proc. SPIE, 7479, 74790B-74790B, doi:10.1117/12.830323, 2009.

Pappalardo, G., Wandinger, U., Mona, L., Hiebsch, A., Mattis, I., Amodeo, A., Ansmann, A., Seifert, P., Linné, H., Apituley, A., Alados Arboledas, L., Balis, D., Chaikovsky, A., D’Amico, G., De Tomasi, F., Freudenthaler, V., Giannakaki, E., Giunta, A., Grigorov, I., Iarlori, M., Madonna, F., Mamouri, R.-E., Nasti, L., Papayannis, A., Pietruczuk, A., Pujadas, M., Rizi, V., Rocadenbosch, F., Russo, F., Schnell, F., Spinelli, N., Wang, X., and Wiegner, M.: EARLINET correlative measurements for CALIPSO: first intercomparison results, J. Geophys. Res.Atmos., 115, D00H19, doi:10.1029/2009JD012147, 2010.

Pappalardo, G., Amodeo, A., Apituley, A., Comeron, A., Freudenthaler, V., Linné, H., Ansmann, A., Bösenberg, J., D’Amico, G., Mattis, I., Mona, L., Wandinger, U., Amiridis, V., AladosArboledas, L., Nicolae, D., and Wiegner, M.: EARLINET: towards an advanced sustainable European aerosol lidar network, Atmos. Meas. Tech., 7, 2389-2409, doi:10.5194/amt-7-23892014, 2014.

Powell, K., Mark, V., Winker, D., Lee, K. P., Pitts, M., Trepte, C., Detweiler, P., Hunt, W., Lambeth, J., Lucker, P., Murray, T., Hagolle, O., Lifermann, A., Faivre, M., Garnier, A., and Pelon, J.: Cloud - Aerosol LIDAR Infrared Pathfinder Satellite Observations (CALIPSO), Data Management System, Data Products Catalog, Document No: PC-SCI-503, Release 3.2, August 2010, NASA Langley Research Center, Hampton, Virginia, USA, 2010.

Rolph, G. D.: Real-time Environmental Applications and Display System (READY) available at: http://www.ready.noaa.gov (last access: 15 December 2014), 2013.

Sekiyama, T. T., Tanaka, T. Y., Shimizu, A., and Miyoshi, T.: Data assimilation of CALIPSO aerosol observations, Atmos. Chem. Phys., 10, 39-49, doi:10.5194/acp-10-39-2010, 2010.

Sissenwine, N., Dubin, M., and Wexler, H.: The U.S. Standard Atmosphere, J. Geophys. Res., 67, 3627-3630, doi:10.1029/JZ067i009p03627, 1962.

Stephens, G. L., Vane, D. G., Boain, R. J., Mace, G. G., Sassen, K., Wang, Z., Illingworth, A. J., O'Connor, E. J., Rossow, W. B., Durden, S. L., Miller, S. D., Austin, R. T., Benedetti, A., and Mitrescu, C.: The cloudsat mission and the A-Train: a new dimension of space-based observations of clouds and precipitation, B. Am. Meteorol. Soc., 83, 1771-1790 + 1742, 2002. 
Vaughan, M., Trepte, C., Winker, D., Avery, M., Campbell, J., Hoff, R., Young, S., Getzewich, B., Tackett, J., and Kar, J.: Adapting CALIPSO Climate Measurements for Near Real Time Analyses and Forecasting, in: Proceedings of the 34th International Symposium on Remote Sensing of Environment, 10-15 April 2011, Sydney, Australia, available at: http://www-calipso.larc.nasa.gov/resources/pdfs/VaughanM_ 211104015final00251.pdf (last access: 24 July 2015), 2011.

Wang, Y., Sartelet, K. N., Bocquet, M., and Chazette, P.: Assimilation of ground versus lidar observations for $\mathrm{PM}_{10}$ forecasting, Atmos. Chem. Phys., 13, 269-283, doi:10.5194/acp-13-2692013, 2013.
Winker, D. M., Vaughan, M. A., Omar, A., Hu, Y., Powell, K. A., Liu, Z., Hunt, W. H., and Young, S. A.: Overview of the CALIPSO mission and CALIOP data processing algorithms, J. Atmos. Ocean. Tech., 26, 2310-2323, doi:10.1175/2009JTECHA1281.1, 2009.

Yu, H., Kaufman, Y. J., Chin, M., Feingold, G., Remer, L. A., Anderson, T. L., Balkanski, Y., Bellouin, N., Boucher, O., Christopher, S., DeCola, P., Kahn, R., Koch, D., Loeb, N., Reddy, M. S., Schulz, M., Takemura, T., and Zhou, M.: A review of measurement-based assessments of the aerosol direct radiative effect and forcing, Atmos. Chem. Phys., 6, 613-666, doi:10.5194/acp-6-613-2006, 2006. 